\title{
PERBANDINGAN HASIL TANGKAPAN UDANG DENGAN MENGGUNAKAN LAPDU, GILTONG DAN TRAMMEL NET DI PERAIRAN SAENGGA KABUPATEN TELUK BINTUNI
}

\author{
Dahri Iskandar ${ }^{I}$ \\ ${ }^{I}$ Departemen Pemanfaatan Sumberdaya Perikanan, FPIK IPB \\ Kampus IPB Dramaga, Bogor 16680 \\ Email:dahri_69@yahoo.com
}

Diserahkan 4 Januari 2010; Diterima 14 Juli 2010

\begin{abstract}
ABSTRAK
Penelitian dilakukan di Perairan Saengga Kabupaten Teluk Bintuni dengan menggunakan 6 (enam) buah trammel net, lapdu dan gilltong. Tujuan penelitian ini adalah untuk membandingkan daya tangkap trammel net, lapdu dan gilltong untuk menangkap udang. Hasil tangkapan total yang diperoleh pada penelitian ini sebanyak 534 ekor yang terdiri dari 25 spesies. Hasil tangkapan dominan adalah udang putih (Penaeus indicus) yakni sebanyak 38.6\% dari total hasil tangkapan diikuti oleh ikan sebelah (Cynoglosus sp) dan tiga waja (Cynoglosus sp) yang masing-masing berjumlah $17.04 \%$ dan $10.11 \%$ dari total hasil tangkapan.
\end{abstract}

Kata Kunci: Trammel Net, Gilltong, Lapdu, Hasil Tangkapan, Udang

\begin{abstract}
This experiment was carried out at Saengga Waters of Teluk Bintuni Regency using 6 (six) pieces of trammel net, lapdu and gilltong, respectively. The objective of this experiment was to compare catchability of trammel net, lapdu and gilltong for capturing shrimp. Total catch obtained in this experiment was 534 fishes which consist of 25 species. Dominant catch was banana prawn (Penaeus indicus) i.e $38.6 \%$ of total catch, followed by flatfish (Cynoglosus sp) and croaker fish (Cynoglosus sp) which consist of $17.04 \%$ and $10.11 \%$ of total catch, respectively. Dominant catch of gilltong and lapdu was dominated by fish while catch of trammel net was dominated by prawn. In term of Catch per Piece of Net, trammel net caught significantly large number of catch than gilltong and lapdu.
\end{abstract}

Key Words: Trammel Net, Gilltong, Lapdu, Catch, Shrimp

\section{PENDAHULUAN}

Udang dapat ditangkap dengan menggunakan berbagai jenis alat tangkap. Di Indonesia saat ini udang ditangkap dengan menggunakan trawl, jaring arad, dogol, sudu dan trammel net. Trawl saat ini berdasarkan ketentuan pemerintah hanya diperbolehkan untuk beroperasi di perairan Arafura. Pada tahun 70'an hingga 80'an trawl merupakan unit penangkapan ikan yang banyak digunakan oleh nelayan.

Dengan bertambahnya armada trawl yang beroperasi di perairan Indonesia mengakibatkan semakin bertambahnya intensitas penangkapan terhadap sumberdaya udang dan sumberdaya ikan demersal lainnya. Selain tekanan terhadap sumberdaya udang dan ikan demersal maka konflik sosial berupa kompetisi untuk memperoleh daerah penangkapan yang sama sering terjadi. Kondisi ini pada akhirnya menimbulkan berbagai peristiwa tindak kekerasan antara armada penangkapan tradisional dan armada trawl. Direktorat jenderal Perikanan mencatat lebih dari 1000 tindak kekerasan terhadap armada trawl di berbagai wilayah di Indonesia (Sarjono, 1980).

Untuk mengatasi konflik horisontal tersebut maka pemerintah segera menerbitkan Keputusan Presiden No 39 tahun 1980 yang melarang pengoperasian armada trawl di Selat Malaka dan 
Pantai Utara Jawa. Pada tahun 1981 pelarangan penggunaan armada trawl diperluas ke seluruh wilayah Indonesia kecuali Laut Arafura melalui Inpres No 11. Dampak dari pelarangan penggunaan armada trawl untuk menangkap udang maupun sumberdaya ikan demersal lainnya adalah terjadinya penurunan produksi udang Indonesia. Selanjutnya, pemerintah melakukan upaya untuk menggantikan alat tangkap trawl dengan alat penangkap udang lainnya. Beberapa alat tangkap sebagai pengganti trawl diujicoba untuk menggantikan peran trawl sebagai alat penangkap utama udang diantaranya trammel net, lapdu maupun giltong.

Perairan Teluk Bintuni merupakan wilayah yang kaya dengan sumberdaya udang. Alat yang digunakan untuk menangkap udang di perairan Bintuni adalah trawl dan trammel net (jaring udang). Beberapa jenis alat tangkap lain seperti jaring lapdu (lapis dua) maupun gilltong (gillnet berkantong) yang pernah populer digunakan oleh nelayan di Pulau Jawa belum dikenal oleh masyarakat Bintuni. Oleh karena itu penelitian ini bertujuan untuk membandingkan daya tangkap antara lapdu, gilltong dan trammel net di Kabupaten Teluk Bintuni.

\section{METODE PENELITIAN}

\section{Alat Tangkap}

Penelitian ini dilakukan di perairan Saengga Kabupaten Teluk Bintuni pada bulan Agustus 2007 dengan menggunakan trammel net sebanyak 6 piece, lapdu 6 piece dan gilltong 6 piece.

Jaring lapdu merupakan jaring yang terdiri dari satu lapis jaring dengan ukuran mata jaring 1.75 inci sedang bagian luar jaring terdapat rangka jaring berbentuk kotak dengan ukuran 30 x 30 $\mathrm{cm}$. Jaring dengan ukuran 1.75 inci berfungsi sebagai kantong untuk menampung hasil tangkapan. Adapun rangka luar jaring berfungsi untuk membentuk kantong ketika jaring dioperasikan dengan cara menghadang arus sehingga ikan tertangkap dan masuk ke dalam kantong. Rangka jaring terbuat dari tali PE $4 \mathrm{~mm}$. Jaring gilltong terdiri dari satu lapis jaring yang mempunyai ukuran mata jaring 1.75 inci dan berfungsi sebagai kantong untuk menampung hasil tangkapan. Lapisan ini terletak pada bagian dalam. Adapun pada bagian luar terdapat rangka luar jaring berbentuk diamond dan berfungsi untuk membentuk kantong sehigga hasil tangkapan dapat masuk dan tertangkap pada kantong jaring. Bukaan maksimum rangka jaring tersebut $50 \mathrm{~cm}$ yang terbuat dari tali PE $4 \mathrm{~mm}$. Trammel net yang digunakan pada penelitian ini terdiri dari 3 lapis jaring dengan ukuran mata jaring pada bagian inner net sebesar 1.75 inci dan outer net 10 inci. Konstruksi lapdu, gilltong dan trammel net yang digunakan pada penelitian ini disajikan pada Gambar 2.

Data diperoleh dengan melakukan uji coba penangkapan ikan (experimental fishing) dengan menggunakan kapal milik nelayan. Alat tangkap berupa trammel net, lapdu dan gilltong dioperasikan dengan metode parallel haul (ICES, 1996). Data berupa jenis hasil tangkapan diidentifikasi untuk diketahui spesiesnya dan jumlah hasil tangkapan pada metode pengoperasian yang berbeda dihitung dan dimasukan ke dalam kantong yang berbeda. Selanjutnya data hasil tangkapan tersebut dianalisis secara kuantitatif dengan menggunakan descriptive statistic



Gambar 1. Lokasi Pengambilan Data Penelitian di Perairan Saengga Kabupaten Teluk Bintuni 

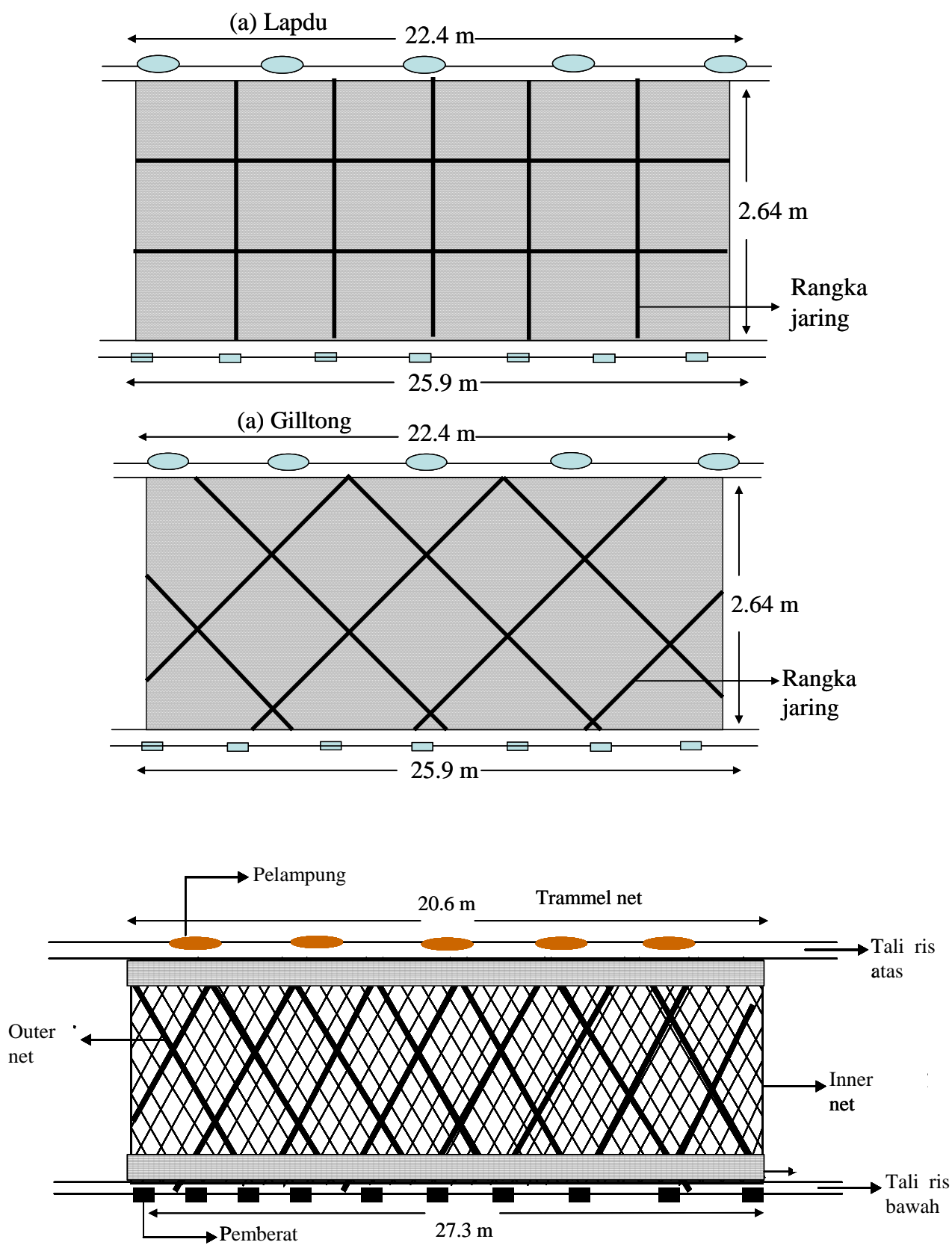

Gambar 2. Konstruksi Lapdu, Gilltong dan Trammel Net yang Digunakan dalam Penelitian 


\section{HASIL DAN PEMBAHASAN}

\section{Keadaan Umum Perikanan Di Wilayah Teluk Bintuni}

Teluk Bintuni merupakan perairan yang kaya akan sumberdaya ikan dan udang hal ini dikarenakan Teluk Bintuni dikelilingi pantai yang ditumbuhi hutan bakau, yang berfungsi sebagai tempat memijah, membesarkan dan mencari makan bagi sebagian jenis ikan dan udang. Potensi perikanan ini dapat dijadikan komoditi unggulan untuk meningkatkan perekonomian di wilayah ini. Pemanfaatan sumberdaya perikanan baik laut, payau, maupun tawar tidak hanya dapat dilakukan dengan cara penangkapan saja, tetapi dapat dilakukan dengan cara budidaya ikan seperti tambak udang dan sebagainya.

Umumnya masyarakat nelayan di Teluk Bintuni melakukan usaha penangkapan dalam skala kecil dan tradisional. Alat tangkap yang digunakan adalah jaring udang (trammel net), jaring hiu/kakap (drive gillnet), pele kali/jaring tuba (barrier net), jala lempar (cast net), jaring kepiting, pancing tangan (hand line) dan pancing rawai (bottom longline) serta gae-gae (pengait) dan serok (scoop net). Usaha penangkapan yang banyak dijumpai di desa-desa Teluk Bintuni adalah penangkapan dengan jala lempar dan jaring udang, sedangkan penangkapan ikan-ikan estuary dengan jaring pele umumnya terdapat di desa-desa yang memiliki banyak anak sungai.

Sumberdaya ikan di perairan ini telah lama dimanfaatkan baik secara tradisional maupun industri. Nelayan yang memanfaatkan sumberdaya ikan secara tradisional terutama berasal dari pesisir Distrik Bintuni dan Babo. Jumlah nelayan dari kedua distrik tersebut tidaklah pasti, sebab selain sebagai nelayan umumnya mereka juga berkebun. Sejak tahun 1970-an terdapat 5 perusahaan penangkapan udang yang mengoperasikan armadanya, namun sejak tahun 1990-an tinggal satu perusahaan penangkap udang yang secara intensif dan reguler mengoperasikan armadanya sepanjang tahun yaitu PT. Bintuni Mina Raya (BMR).

Pengembangan sektor kelautan dan perikanan Kabupaten Teluk Bintuni banyak menjanjikan harapan baru bila dikelola secara profesional dengan dukungan teknologi penangkapan serta penyediaan sarana dan prasarana yang memadai.

Perairan Teluk Bintuni memiliki potensi sumberdaya ikan sangat tinggi hal ini karena perairannya dikelilingi hutan mangrove yang merupakan salah satu hutan mangrove peling luas di dunia dengan kerapatan tanaman yang sangat tinggi. Hutan mangrove disamping berfungsi sebagai green belt atau pengaman pantai juga sebagai tempat ikan bertelor, memijah, dan berkembang biak. Kawasan hutan mangrove juga merupakan habitat yang sangat baik bagi pertumbuhan udang (Anonimous, 2007)

\section{Total Hasil Tangkapan Selama Penelitian}

\section{Komposisi Total Hasil Tangkapan}

Total jumlah hasil tangkapan yang diperoleh dalam uji coba ketiga jenis alat tangkap tersebut adalah 534 ekor yang terdiri atas 25 spesies. Hasil tangkapan dominan yang diperoleh dalam uji coba ini adalah udang putih (Penaeus indicus) yakni sebanyak $38.6 \%$ dari total hasil tangkapan, diikuti oleh ikan lidah (Cynoglosus sp) sebanyak $17.04 \%$ dan tiga waja (Nibea albiflora) sebanyak $10.11 \%$. Hasil selengkapnya dapat dilihat pada Tabel 1 .

Tabel 1. Jumlah dan Jenis Hasil Tangkapan yang Diperoleh dalam Penelitian

\begin{tabular}{|c|c|c|c|}
\hline$\overline{\text { No }}$ & Jenis Ikan & Jumlah (ekor) & Persentase (\%) \\
\hline 1 & Belanak & 1 & 0,19 \\
\hline 2 & Belut laut & 3 & 0,56 \\
\hline 3 & Bilis & 7 & 1,31 \\
\hline 4 & Kepala batu & 8 & 1,5 \\
\hline 5 & Bulan-bulan & 30 & 5,62 \\
\hline 6 & Buntal & 6 & 1,12 \\
\hline 7 & Hiu & 20 & 3,75 \\
\hline 8 & Kapas-kapas & 6 & 1,12 \\
\hline 9 & Kepiting bakau & 1 & 0,19 \\
\hline 10 & Lele laut & 1 & 0,19 \\
\hline 11 & Lidah & 91 & 17,04 \\
\hline 12 & Lobster & 2 & 0,37 \\
\hline 13 & Mulut tikus & 2 & 0,37 \\
\hline 14 & Pepetek & 17 & 3,18 \\
\hline 15 & Puri(teri) & 1 & 0,19 \\
\hline 16 & Rajungan & 1 & 0,19 \\
\hline 17 & Rajungan api & 3 & 0,56 \\
\hline 18 & Sebelah & 4 & 0,75 \\
\hline 19 & Sembilang & 25 & 4,68 \\
\hline 20 & Tiga waja & 54 & 10,11 \\
\hline 21 & Tulang-tulang & 26 & 4,87 \\
\hline 22 & Udang cakrek & 17 & 3,18 \\
\hline 23 & Udang kipas & 1 & 0,19 \\
\hline 24 & Udang putih & 206 & 38,58 \\
\hline 25 & Udang windu & 1 & 0,19 \\
\hline & Total & 534 & 100 \\
\hline
\end{tabular}


Hasil tangkapan yang diperoleh didominasi oleh udang putih (Penaeus indicus) menunjukan bahwa perairan yang merupakan daerah penangkapan trammel net tersebut merupakan wilayah yang subur. Daerah tersebut merupakan wilayah paparan yang tidak jauh dari muara sungai, pada jarak 60-80 mil dari pantai dengan kedalaman perairan 8-40 meter (Naamin dan Uktolsedja, 1976). Selanjutnya Naamin dan Uktolsedja (1976) menambahkan bahwa udang menyenangi daerah yang terjadi percampuran air sungai dan air laut, karena di daerah ini banyak terdapat makanan serta zat-zat hara yang dibutuhkan udang

\section{Komposisi Hasil Tangkapan Gilltong}

Gilltong dioperasikan pada kedalaman $0.9 \mathrm{~m}-$ $5.9 \mathrm{~m}$. Jumlah total hasil tangkapan yang diperoleh alat tangkap gilltong pada uji coba ini sebanyak 58 ekor yang terdiri atas 15 spesies. Hasil tangkapan dominan gilltong adalah ikan lidah (Cynoglossus sp) dengan jumlah sebanyak $31.05 \%$ dari total hasil tangkapan, diikuti oleh ikan tigawaja (Nibea albiflora) dengan jumlah sebanyak $20.7 \%$. Hasil tangkapan udang putih (Penaeus indicus) hanya senesar $6.3 \%$ dari total hasil tangkapan. Selengkapnya komposisi hasil tangkapan gilltong yang diperoleh dalam uji coba ini disajikan pada Gambar 3



Gambar 3. Komposisi Hasil Tangkapan Gilltong yang Diperoleh dalam Penelitian

\section{Komposisi Hasil Tangkapan Lapdu}

Total jumlah hasil tangkapan lapdu yang diperoleh pada uji coba ini sebanyak 80 ekor yang terdiri atas 14 spesies ikan. Dominan ikan yang tertangkap dengan menggunakan lapdu adalah ikan lidah (Cynoglossus sp) sebanyak 32.5\% dari total hasil tangkapan, diikuti oleh ikan bulanbulan sebanyak $10 \%$. Hasil tangkapan udang hanya sebesar $2.5 \%$ dari total hasil tangkapan. Secara lebih detail komposisi hasil tangkapan yang diperoleh pada alat tangkap lapdu dapat dilihat pada Gambar 4.



Gambar 4. Komposisi Hasil Tangkapan Lapdu yang Diperoleh dalam Uji Coba

\section{Komposisi Hasil Tangkapan Trammel Net}

Trammel net dioperasikan pada kedalaman 0.9 $\mathrm{m}-2.6 \mathrm{~m}$. Total jumlah hasil tangkapan trammel net yang diperoleh pada uji coba ini sebanyak 396 ekor yang terdiri atas 23 spesies ikan. Dominan hasil tangkapan trammel net adalah udang putih (Penaeus indicus) sebanyak 50.5\% dari total hasil tangkapan, diikuti oleh ikan lidah sebanyak $11.9 \%$, dan tiga waja sebanyak $8.8 \%$. Secara lebih detail komposisi hasil tangkapan yang diperoleh pada alat tangkap trammel net dapat dilihat pada Gambar 5. 


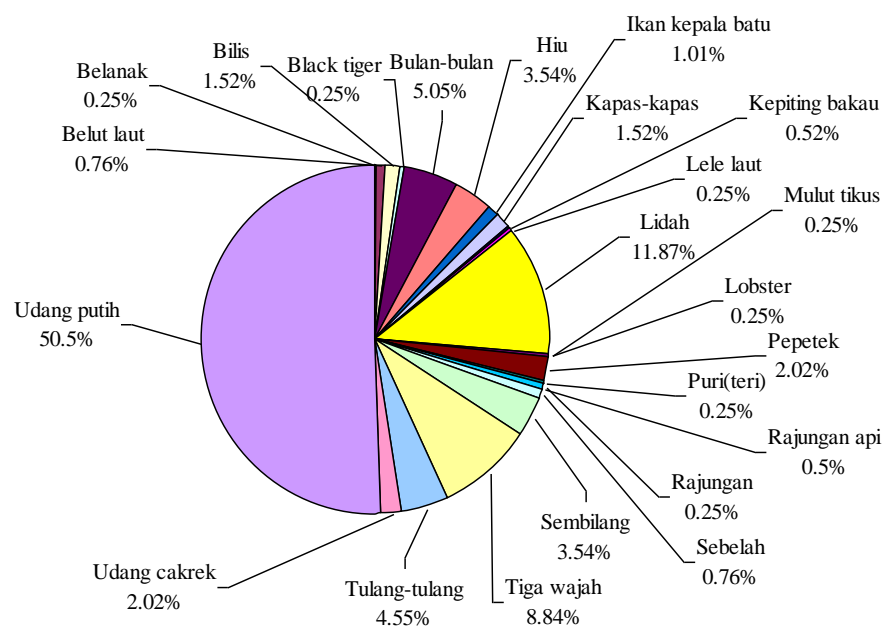

Gambar 5. Komposisi Hasil Tangkapan Lapdu yang Diperoleh dalam Uji Coba

Berdasarkan hasil tangkapan ketiga jenis alat tangkap yang diuji coba maka hasil tangkapan gilltong dan lapdu didominasi oleh ikan dengan proporsi sekitar $30 \%$ sedangkan trammel net didominasi oleh udang putih yakni dengan proporsi sekitar 50\% dari hasil tangkapan trammel net. Dominasi hasil tangkapan ikan pada gilltong maupun lapdu dapat diakibatkan oleh dua hal. Kondisi yang pertama dapat diakibatkan oleh sistem pengoperasian alat tangkap yang menggunakan sistem pasif. Pada pengoperasian dengan sistem pasif maka hasil tangkapan yang diperoleh sangat tergantung pada arah arus yang bergerak melalui alat tangkap. Apabila arus bergerak dari bagian belakang alat tangkap lapdu maupun gilltong maka kantong yang diharapkan bisa terbentuk untuk membentuk kantong (pocketing) tidak bisa terbentuk sehingga fungsinya berubah menjadi gillnet. Pada kondisi seperti ini maka lapdu dan gilltong berperan sebagai penghadang ikan. Oleh karena itu maka hasil tangkapan lapdu maupun gilltong banyak didominasi oleh ikan sedangkan udang hanya sekitar 3-7 \% dari hasil tangkapan lapdu maupun gilltong. Ditinjau dari proses tertangkapnya, maka udang lebih banyak dengan cara terpuntal (Goni, et.al., 2003). Ikan maupun udang akan tertangkap dengan cara terpuntal apabila jaring berada dalam keadaan kendur (loose) atau memiliki hanging ratio yang rendah. Pada kondisi seperti ini maka baik lapdu maupun gilltong sebaiknya dioperasikan secara aktif yankni dengan ditarik oleh perahu sehingga kantong bisa terbentuk dengan sempurna.

Sebaliknya pada hasil tangkapan trammel net lebih banyak didominasi oleh udang putih yang merupakan target penangkapan. Hal ini karena konstruksi trammel net yang terdiri dari tiga lapis sehingga pada saat trammel net dioperasikan secara pasif arah arus yang datang dari bagian depan maupun belakang alat tangkap tersebut masih dapat membentuk kantong (pocketing) untuk menangkap udang. Selain itu jaring pada bagian outer net maupun inner net relatif kendur sehingga udang bisa tertangkap dengan baik secara entangled (terpuntal)

\section{Perbandingan Hasil Tangkapan Tiap Piece Jaring}

Ditinjau dari hasil tangkapan per piece jaring atau hasil tangkapan per upaya penangkapan (CPUE), alat tangkap trammel net menangkap ikan maupun udang yang secara signifikan lebih besar dibandingkan alat tangkap jenis gilltong maupun lapdu. Hasil tangkapan total trammel net per piece jaring (CPUE) adalah 11 ekor sedangkan hasil tangkapan trammel net per piece jarring untuk udang adalah 5.6 ekor (Gambar 6). Hasil tangkapan trammel net ini secara signifikan lebih besar dibandingkan hasil tangkapan lapdu maupun gilltong. Secara lebih rinci hasil tangkapan per piece jaring untuk total hasil tangkapan maupun hasil tangkapan per piece jaring untuk udang yang diperoleh masing-masing jenis alat tangkap disajikan pada Gambar 6 .

Hasil tangkapan per upaya penangkapan (CPUE) yang diperoleh trammel net untuk udang putih maupun total hasil tangkapan secara keseluruhan secara signifikan lebih besar dibanding lapdu maupun gilltong. Hal ini diduga diakibatkan oleh ketebalan benang (twine thickness) yang digunakan oleh trammel net lebih kecil dibandingkan dengan lapdu maupun jaring gilltong. Yokota, et.al. (2001) mengungkapkan fakta bahwa penggunaan gillnet dengan nomor 0.8 menangkap rainbow trout (Oncorhyncus mycis) dengan selang ukuran yang lebih lebar dibanding dengan gillnet yang menggunakan benang nomor 3. Andreev (1955) sebagaimana diacu dalam Hamley (1976) juga menyatakan bahwa jaring dengan twine thickness lebih kecil menangkap ikan lebih banyak dibanding gillnet dengan bahan jaring dengan diameter lebih benang lebih besar. Namun demikian benang yang terlalu kecil akan 
mengakibatkan jaring mudah rusak, ikan terpuntal lebih dalam sehingga sulit untuk dilepas. Hamley (1976) menyatakan bahwa jaring yang menggunakan benang lebih tipis akan kurang terlihat ketika berada di perairan dan lebih mudah terentang aehingga lebih mudah untuk menjerat ikan. Pada penelitian ini penggunaan nomor benang untuk bahan jaring trammel net yang lebih kecil dibanding lapdu maupun gilltong karena ketiadaan nomor benang yang sama untuk trammel net di pasar. Pada penelitian ini tinggi jaring maupun panjang jaring dalam keadaan terpasang tidak berpengaruh terhasil hasil tangkapan per upaya penangkapan. Karena gilltong memiliki ukuran tinggi dan panjang terpasang yang lebih baik dibanding alat tangkap lainnya tetapi hasil tangkapannya masih lebih sedikit dibanding trammel net.

\section{KESIMPULAN}

1) Hasil tangkapan dominan yang diperoleh dalam uji coba ini adalah udang putih (Penaeus indicus) yakni sebanyak 38.6\% dari total hasil tangkapan, diikuti oleh ikan lidah (Cynoglosus sp) sebanyak $17.04 \%$ dan tiga waja (Nibea albiflora) sebanyak $10.11 \%$.

2) Hasil tangkapan gilltong dan lapdu didominasi oleh ikan dengan proporsi sekitar $30 \%$ sedangkan trammel net didominasi oleh udang putih yakni dengan proporsi sekitar $50 \%$ dari hasil tangkapan trammel net.

3) Ditinjau dari hasil tangkapan per piece jaring atau hasil tangkapan per upaya penangkapan (CPUE), alat tangkap trammel net menangkap ikan maupun udang yang secara signifikan lebih besar dibandingkan alat tangkap jenis gilltong maupun lapdu

\section{UCAPAN TERIMA KASIH}

Penulis mengucapkan terima kasih kepada Projek Kerjasama LPPM IPB dengan BP Tangguh yang telah memfasilitasi dan mendanai kegiatan ini. Penulis juga mengucapkan terima kasih kepada Bapak Lambredt dan Abdullah Kamisopa yang telah membantu penulis dalam pelaksanaan uji coba.



Gambar 6. Jumlah Total Hasil Tangkapan Per Piece Jaring (A) dan Hasil Tangkapan Udang (b) pada Lapdu, Gilltong dan Trammel Net Selama Penelitian 


\section{DAFTAR PUSTAKA}

Anonimous. 2007. Studi perikanan berkelanjutan di Teluk Bintuni, Papua. Laporan Survey Kerjasam Institut Pertanian Bogor dan Proyek Tangguh. 119 hal.

Andreev, N. 1955. Some problems in the theory of the capture fish by gillnets. Tr. Vses. Naucho - Issled. Inst. Morsk. Rybn. Khoz. Okeanogr. 30:109-127 (Translated from Russian by Fish. Lab., Lowestoft, England., 30 p)

Goni, R, Quetglas, A., Renones, O. 2003. Differential catchability of male and female European spiny lobster Panulirus elephas (Fabricius, 1787) in traps and trammel nets. Fish.Res.; 65:295-307
Hamley, J.M. Review on gillnet selectivity. $J$. Fish. Res. Board Can. 1975;32: 1943-1969

ICES. .1996. Manual of methods of measuring the selectivity of towed fishing gear. International Council for the Exploration of The Sea. In: Willeman, D.A., Ferro, RST., Fonteyn, R., Millar., R.B (Eds). Denmark. $125 \mathrm{p}$

Naamin dan Uktolsedja. 1976. Status perikanan udang di Kalimantan Selatan dan Timur. LPPL. Jakarta

Sardjono, I. 1980. Trawlers banned in Indonesia. ICLARM Newsletter, 3(4), p3

Yokota, K., Fujimori, Y., Shiode D. and Tokai, T. 2001. Effect of thin twine on gill net sizeselectivity analyzed with the direct estimation method. Fish. Sci.; 67, 851-856 